\title{
Marketing Practices and Marketing Efficiency of Organic Minor Millets in Tamil Nadu, India
}

\author{
M. Anjugam ${ }^{*}$ and T. Alagumani ${ }^{2}$ \\ ${ }^{1}$ Department of Agricultural Economics, Tamil Nadu Agrl. University, Coimbatore, India \\ ${ }^{2}$ Department of Trade and Intellectual Property, TNAU, Coimbatore, India \\ *Corresponding author
}

\section{A B S T R A C T}

The study was conducted in Dharmapuri district, Tamil Nadu to examine the cost and returns of organic ragi production and to analyze the marketing efficiency and constraints

Keywords

Organic farming,

Ragi, Marketing

channel, Price spread,

Marketing efficiency

Article Info

Accepted:

22 July 2019

Available Online:

10 August 2019 in marketing. Certified organic farmers who got group organic certification from TNOCD were contacted for the study. Cost of cultivation and returns were assessed using CACP approach and marketing channel was identified. Price spread and marketing efficiency was assessed using Acharya's approach for the identified marketing channel. The cost of cultivation of organic ragi was Rs. 27137 per ha, of which the share of family labour alone 27 per cent and the share of human labour was nearly 52 per cent. Net income per ha was Rs.73215. Price spread was higher in ragi cookies (79\%) and lower in ragi flour (41\%). The farmer's share in consumer price was higher in ragi flour (59\%) and lower in cookies $(21 \%)$. Marketing efficiency was higher in ragi flour than cookies and sprouted flour. Hence farmers should be educated on improved varieties for getting higher yield. Processing units may be supplied to the Organic Farmers Association at free of cost for value addition so as to increase the farmer's net income and to provide additional employment. Self-help Group or Joint Liability Group's may be organized among the members so as to start up new enterprises relating to value addition and opening retail outlets on their own to get sustainable income.

\section{Introduction}

Organic products are grown under a system of agriculture without the use of chemical fertilizers and pesticides with an environmentally and socially responsible approach. Consumer demand increases, reflected in the significant market growth of $11.5 \%$ in the US, the world's largest organic market. Globally, 181 countries are reporting organic farming activities (FiBL-IFOAM,
2019). Organic Monitor - a Market research company estimates the global market for organic products has increased from 72 billion US Dollars in 2013 to 97 billion US Dollars in 2017. The United States is the leading market with 40 billion euros followed by Germany (10 billion euros) and France (7.9 billion euros) and China (2.4 billion euros) the fourth biggest organic market in the world. The highest per capita spending was found in Switzerland (288 euros), Denmark (278 euros) 
and Sweden (237 euros). Two million organic producers reported in 2013 have increased to 2.9 million producers in 2017 and India (835000) has the highest number of producers in the world followed by Uganda (210352) and Mexico (210000). During 2017, a total of 69.8 million hectares were organic representing Australia is the country with the largest organic agriculture land (35.6 million ha) followed by Argentina (3.4 million ha) and China (3.0 million ha). The countries with the largest share of organic agricultural land of their total farmland are Liechtenstein $(37.9 \%)$, Samoa (37.6\%) and Austria (24\%).

India ranks $9^{\text {th }}$ position among the top ten countries in terms of cultivable land area under organic and $1^{\text {st }}$ in terms of number of producers. The certified area includes 3.56 million ha including forest and wild area for collection of minor forest produces. The Government of India has implemented the National Programme for Organic Production (NPOP) involves the accreditation programme for Certification Bodies, standards for organic production, promotion of organic farming, etc. The NPOP standards for production and accreditation system have been recognized by European Commission, Switzerland and USDA as equivalent to their country standards.

In Tamil Nadu, Tamil Nadu Organic Certification Department (TNOCD) was established during 2007-2008 to carryout inspection and certification of organic production system in accordance with NPOP under the Foreign Trade and Development Act (FTDR Act). TNOCD is accredited by APEDA (Agricultural and Processed Food Products Exports Development Authority), New Delhi, Ministry of Commerce and Industry, Government of India. TNOCD also imparts free training to registered organic farmers on National Standards for Organic Production, and Tamil Nadu Organic
Certification Department Standards. During the year 2010-11, 28114 acres of land have been registered under Organic Certification by 8372 individual farmers in Tamil Nadu and has increased to around 29799 acres during 2017-18. In addition, 32 corporate farms and organic farmers associations obtained group organic certification (www. tnocd.net)

Narayanan (2005), Dhaka (2008) indicated that the major constraints faced by the Indian organic farmers were lack of awareness, shortage of bio-mass, inadequate supporting infrastructure, high input cost, lack of financial support, lack of established markets (Saranya,2011), low yield, high labour requirements (Svotwa et al., 2008). According to Kumar (2010), the constraints faced by the organic farmers were the poor awareness about utility and importance of organic farming, lack of skilled manpower, lack of information about the availability of organic products and lack of proper co-ordination among researchers, extension workers and farmers.

Chandrasekaran et al., (2017) revealed that cost of cultivation per ha was generally higher under organic cultivation which ranges from Rs.1581 to Rs.17466 as a result of high labour requirements. The net incomes were consistently lower by 18 to 41 per cent in case of paddy. The study revealed that direct marketing of processed organic rice with organic label was found to be profitable with the net income of Rs.28635/acre at a premium price realized compared to Rs.12617/acre under conventional cultivation.

With this background, the present study aimed to analyze the marketing of organic minor millets and its products in Tamil Nadu with the following specific objectives. They are;

To examine the cost of cultivation and returns in organic minor millets, 
To trace the marketing channel and to estimate the price spread, value addition of organic minor millets, if any, and

To assess the marketing efficiency of organic minor millets in the study area.

\section{Materials and Methods}

Tamil Nadu forms the universe of the study. Multi-stage purposive and random sampling was followed for selection of study district, study block and sample respondents. Dharmapuri district was purposively selected for the study since it is the second largest producer of minor millets in terms of area i.e. 22 per cent of the total area under Tamil Nadu. Harur block of Dharmapuri district in Tamil Nadu was purposively selected based on the highest area under minor millets.

Also, organic farmers association functioning in the block got "Group Organic Certification" from Tamil Nadu Organic Certification Department (TNOCD), Coimbatore. Hence, in Harur block, 30 organic farmers were selected at random. Post stratification of sample farms was done based on the cropping pattern and three minor millets crops viz., Finger millet, Little millet and Foxtail millet were grown by the sample farmers. Since, in all the sample farms, ragi was grown as a major crop, ragi was selected for further analysis. For tracing the marketing channel, different stakeholders' viz., organic farmer association, processors and retailers were contacted. The primary data was collected through personal interview method using well-structured and pre-tested interview schedule.

\section{Tools of Analysis}

\section{Cost and returns}

Cost and returns of ragi under organic farming was estimated using CACP approach.

\section{Cost A1}

Value of hired human labour, value of owned and hired bullock power, value of owned and hired machinery charges, value of seed, value of organic insecticides and pesticides, value of FYM and

Organic inputs, irrigation charges, depreciation on implements and farm building, land revenue, cesses and other taxes, and interest on working capital.

Cost $\mathrm{A} 2=$ Cost $\mathrm{A} 1+$ Rent paid for leased in land

Cost $\mathrm{B} 1=$ Cost $\mathrm{A} 1+$ interest value of owned fixed capital assets (excluding land)

Cost $\mathrm{B} 2=$ Cost $\mathrm{B} 1+$ Rental value of owned land (net of land revenue) and rent paid for leased in land

Cost $\mathrm{C} 1=$ Cost $\mathrm{B} 1+$ Imputed value of family labour

Cost C2 = Cost B2 + Imputed value of family labour

Cost C3 $=$ Cost $\mathrm{C} 2+10 \%$ of Cost $\mathrm{C} 2$ (managerial functions performed by the farmer).

Cost C3 is the total cost of cultivation.

Gross Income $($ Rs. $/$ ha $)=$ Total Yield X Price

Net Income $($ Rs./ha $)=$ Gross Income - Total Cost

\section{Price spread}

Concurrent margin method was used to estimate the price spread and the farmer's share in consumers' rupee for the identified marketing channel. 
The farmer's share in consumer rupee $(\mathrm{FS})=$ (FP / CP) X 100

Where,

FS - Farmer's share in consumer rupee (\%)

FP - Farmer's net selling price

$\mathrm{CP}$ - Consumer's price

Same formula was used to know the share of different market intermediaries in consumer rupee in terms of marketing cost and marketing margin.

\section{Marketing efficiency}

Marketing efficiency was calculated using Acharya's Approach for value added products for unit quantity.

$\mathrm{ME}=\mathrm{FP} \div(\mathrm{MC}+\mathrm{MM})$

Where,

ME - Marketing efficiency

FP - Price received by the farmer

MC - Total marketing cost

MM - Net marketing margin

\section{Results and Discussion}

\section{General Characteristics of Sample Farmers}

Profile of the sample farmers revealed that (Table 1) of the total sample farmers, more than 60 per cent of the sample farmers were in the age group of 31 to 50 years and they are actively involved in cultivation of organic minor millets. The average age of the sample farmers was about 47 years. About $1 / 3^{\text {rd }}$ of the sample organic minor millets farmers were illiterates and half of them had high school level of education. Average family size of the sample farmers in was five. The average farming experience was 33 years whereas the average experience in organic farming was around 8 years. Marginal and small farmers accounted for 93 per cent of the sample households with an average farm size of 1.34 ha. In terms of area under irrigation, 53 per cent of gross cropped area depends on rainfed cultivation and 47 per cent by open well. Finger millet, Little millet and Foxtail millet alone accounted for 52.31 per cent of the gross cropped area of the sample farms. Since ragi was grown in all the sample farms, ragi was chosen for analysis. They use only local varieties in their farm and gave three irrigations on an average during the crop period under organic. The milch cow per farm was 1.60 with a mean value of Rs.18704 and it is inferred that all the sample farmers possessed milch animal.

\section{Reasons for Shift over to Organic Farming}

Majority of the sample farmers shifted to organic farming (Table 2) because of motivation by NGO ( 83 per cent), to stay healthy \& to produce safety food for themselves and others (30 per cent) and for chemical free environment (17 per cent). NGO plays a major role in educating the farmers group to produce organic crops for their own consumption and at the same time to earn more and to supply organic products for other consumers. With regard to organic inputs application, 72 per cent of the sample farmers used farmyard manure in minor millet cultivation followed by panchakavya (21 per cent) and leaves extract (11 per cent). Only six per cent of them used organic pesticide since the pest \& disease incidence is found to be very low.

\section{Economics of Organic Ragi}

\section{Cost of Cultivation}

The cost of cultivation analysis using CACP approach (Table 3) revealed that the total cost of cultivation of ragi was Rs.27137 per ha. Of 
which, the operational cost accounted for nearly 52 per cent. The imputed value of family labour alone accounted for 27 per cent to Cost C3. Interest on owned fixed capital was found to be very low (i.e) about two per cent of the total cost. Because investment on fixed capital by the sample farmers was very meager may be the sample farmers are from marginal and small farmer category. The higher share of family labour indicated that the role of family labour is high in case of organic cultivation. Overall, share of human labour alone including hired labour accounted for 50 per cent. It is concluded from the result that organic ragi cultivation is found to be labour intensive particularly family labour.

\section{Returns from Organic Ragi Production}

The details relating to yield and income measures for the organic ragi cultivation was worked out and the results are presented in Table 4.

The average yield of ragi was $31.36 \mathrm{Qtl} / \mathrm{ha}$ with an average price of Rs.3200 per Qtl. Net income per hectare was Rs.73215.

Cost of production was Rs.865 per qtl of ragi and was lower than average price realized by the farmer. This may be due to higher price offered by the organic farmer association over the market price.

Table.1 Profile of Sample Farmers

\begin{tabular}{|c|c|c|c|}
\hline S. No. & Particulars & No. of farmers $(\mathrm{N}=30)$ & Per cent to total \\
\hline 1 & Average age (Yrs) & 47.27 & \\
\hline \multirow[t]{5}{*}{2} & Education & & \\
\hline & Illiterates & 9 & 30.00 \\
\hline & Primary & 10 & 33.33 \\
\hline & High school & 6 & 20.00 \\
\hline & Higher Secondary and above & 5 & 16.67 \\
\hline 3 & Average Family Size (Nos.) & 5.00 & \\
\hline 4 & Average farming experience (Yrs) & 33.29 & \\
\hline 5 & $\begin{array}{l}\text { Average organic farming experience } \\
\text { (Yrs) }\end{array}$ & 8.32 & \\
\hline \multirow[t]{5}{*}{6} & Farm size & & \\
\hline & Marginal farms $(<1 \mathrm{ha})$ & 16 & 53.33 \\
\hline & Small farms (1-2 ha) & 12 & 40.00 \\
\hline & Medium farms (2-4 ha) & 2 & 6.67 \\
\hline & Average farm size (ha) & 1.34 & \\
\hline 7 & Possession of milch cow (Nos./farm) & 1.60 & 100.00 \\
\hline
\end{tabular}

Source: Primary survey, 2017

Table.2 Reasons for shifting to Organic cultivation

\begin{tabular}{|c|l|c|c|}
\hline S. No. & \multicolumn{1}{|c|}{ Particulars } & No. of Farmers & Per cent to total \\
\hline $\mathbf{1}$ & Motivation by NGO & 25 & 83.00 \\
\hline $\mathbf{2}$ & Health \& Safety Food & 9 & 30.00 \\
\hline $\mathbf{3}$ & Chemical Free Environment & 5 & 17.00 \\
\hline
\end{tabular}


Table.3 Cost of Cultivation of Organic Ragi

\begin{tabular}{|c|l|c|c|}
\hline S. No. & \multicolumn{1}{|c|}{ Particulars } & Amount (Rs./ha) & \% to Total cost \\
\hline $\mathbf{1}$ & Cost A1 & 14104 & 51.97 \\
\hline $\mathbf{2}$ & Cost A2 & 14104 & 51.97 \\
\hline $\mathbf{3}$ & Cost B1 & 14533 & 53.55 \\
\hline $\mathbf{4}$ & Cost B2 & 17366 & 63.99 \\
\hline $\mathbf{5}$ & Cost C1 & 21837 & 80.47 \\
\hline & Imputed value of family labour & 7304 & 26.91 \\
\hline $\mathbf{6}$ & Cost C2 & 24670 & 90.91 \\
\hline $\mathbf{7}$ & Cost C3 & 27137 & 100.00 \\
\hline
\end{tabular}

Table.4 Returns from Organic Finger Millet Cultivation

\begin{tabular}{|c|l|c|}
\hline S. No. & \multicolumn{1}{|c|}{ Particulars } & Value (Rs./ha) \\
\hline $\mathbf{1}$ & Average yield (Qtl/ha) & 31.36 \\
\hline $\mathbf{2}$ & Average price (Rs./Qtl) & 3200 \\
\hline $\mathbf{3}$ & Gross Income (GI) & 100352 \\
\hline $\mathbf{4}$ & Cost of Cultivation & 27137 \\
\hline $\mathbf{5}$ & Cost of Production (Rs./Qtl) & 865 \\
\hline $\mathbf{6}$ & Net Income & 73215 \\
\hline
\end{tabular}

Table.5 Price Spread of Organic Ragi

(Rs. Per quintal)

\begin{tabular}{|c|c|c|c|c|c|c|}
\hline \multirow[t]{3}{*}{ Particulars } & \multicolumn{6}{|c|}{ Finger millet } \\
\hline & \multicolumn{2}{|c|}{ Cookies } & \multicolumn{2}{|c|}{ Flour } & \multicolumn{2}{|c|}{ Sprouted flour } \\
\hline & Value & $\%$ & Value & $\%$ & Value & $\%$ \\
\hline \multicolumn{7}{|l|}{ Farmer } \\
\hline Sale price & 3200 & 20.5 & 3200 & 59.3 & 3200 & 37.7 \\
\hline Cost & 24 & 0.2 & 24 & 0.4 & 24 & 0.3 \\
\hline Net Price & 3176 & 20.4 & 3176 & 58.8 & 3176 & 37.4 \\
\hline \multicolumn{7}{|c|}{ Organic Farmer Association cum Processor } \\
\hline Purchase price & 3200 & 20.5 & 3200 & 59.26 & 3200 & 37.65 \\
\hline Cost & 58 & 0.4 & 58 & 1.07 & 58 & 0.68 \\
\hline Value Addition & 6575 & 42.2 & 495 & 9.17 & 475 & 5.59 \\
\hline Total cost & 6633 & 42.5 & 553 & 10.24 & 533 & 6.27 \\
\hline Margin & 3687 & 23.6 & 747 & 13.83 & 3517 & 41.38 \\
\hline \multicolumn{7}{|l|}{ Retailer } \\
\hline Purchase price & 13520 & 86.7 & 4500 & 83.3 & 7250 & 85.29 \\
\hline cost & 60 & 0.38 & 80 & 1.48 & 80 & 0.94 \\
\hline margin & 2020 & 12.95 & 820 & 15.19 & 1170 & 13.76 \\
\hline Consumer Price & 15600 & 100.00 & 5400 & 100.00 & 8500 & 100.00 \\
\hline Price spread & 12400 & 79.64 & 2200 & 41.18 & 5300 & 62.63 \\
\hline \multicolumn{7}{|l|}{$\begin{array}{l}\text { Per Kg of final } \\
\text { product }\end{array}$} \\
\hline \multicolumn{7}{|l|}{ Farmer's share } \\
\hline Price Spread & & & & & & \\
\hline
\end{tabular}


Table.6 Marketing Efficiency of Organic Ragi -Acharya’s approach

\begin{tabular}{|l|c|c|c|}
\hline \multicolumn{1}{|c|}{ Products } & $\begin{array}{c}\text { Price received by the } \\
\text { farmer (Rs./qtl) }\end{array}$ & $\begin{array}{c}\text { Marketing Cost + } \\
\text { Marketing Margin (Rs./qtl) }\end{array}$ & $\begin{array}{c}\text { Marketing } \\
\text { Efficiency }\end{array}$ \\
\hline Cookies & 3176 & 12400 & 0.26 \\
\hline Flour & 3176 & 2200 & $\mathbf{1 . 4 4}$ \\
\hline Sprouted flour & 3176 & 5300 & 0.60 \\
\hline
\end{tabular}

\section{Marketing Channel}

The sample organic minor millets growers in the study area were marginal and small farmers and they sell their produce only to the Sitilingi Organic Farmers Association (SOFA) who got group organic certification. There are more than 500 organic farmers in SOFA. They sell entire produce only to the SOFA where value addition is being done and it is sold to other organic shops. Farmers are not doing any kind of value addition activities such as grading, processing, etc at farm level. FPC provides technical assistance in growing organic crops, supply of organic inputs and procurement of produce from the farmers at a reasonable price compared to open market. It is also involved in value addition and manufactures organic minor millets products such as cookies, flour, sprouted flour, rice, pappad, etc. FPC organizes organic farmers group through field officers. Field officers visit the farm at regular intervals and guide the farmers. They are supporting the farmers by giving livestock at no interest, building cattle shed, providing seedlings at a subsidized rate, conducting training in preparation of organic inputs, providing drums to prepare organic inputs, providing sprayer to the group at free of cost, etc. The marketing channel for organic ragi identified is as follows.

Organic Farmer $\rightarrow$ Organic Farmers Association Cum Processor $\rightarrow$ Retialer $\rightarrow$ Consumer

\section{Price spread of Organic Ragi}

The price received by the producer was
Rs.3200/quintal for grain. The organic farmer association cum processor produced $52 \mathrm{~kg}$ of organic finger millet cookies, $60 \mathrm{~kg}$ of organic finger millet flour and $50 \mathrm{~kg}$ of sprouted organic finger millet flour from one quintal of organic ragi grain. The price spread analysis for ragi products was estimated and is presented in Table 5 .

The results revealed that the net price received by the farmer in the consumer rupee was 20.36 per cent, 58.81 per cent and 37.36 per cent for cookies, flour and sprouted flour, respectively. The price spread for ragi cookies, flour and sprouted flour in the consumer price was 79.64 per cent, 41.18 per cent and 62.63 per cent, respectively in the consumer price. Hence, it is concluded that price spread was higher in case of cookies followed by sprouted flour due to increase in share of value addition.

\section{Marketing Efficiency}

The marketing efficiency of identified marketing channel for organic ragi was estimated using Acharya's approach (Table 6). According to Acharya's approach, marketing efficiency was relatively higher for finger millet flour (1.44) followed by sprouted finger millet flour (0.60).

Based on the results of the study, it is concluded that the share of family labour was found to be high on the total cost of cultivation in organic ragi and the share of human labour accounted for nearly 50 per 
cent of the total cost. Net income per ha was Rs.86015. The price spread was higher in finger millet cookies and lower in flour. The farmer's share in consumer price was higher in finger millet flour and lower in cookies. Marketing efficiency was relatively higher in finger millet flour. The net value addition was higher in case of cookies and sprouted flour. Hence, the study suggested that the farmers should be educated on latest improved varieties for getting higher yield. Minor millet processing units may be supplied to the Organic Farmers Association at free of cost for value addition at group level so as to increase the farmer's share in consumer price and also to provide additional employment. Self Help Group and Joint Liability Group's may be organized among the Organic Farmers Association members so as to start up new enterprises relating to value addition and opening retail outlets on their own to get sustainable income.

\section{Acknowledgement}

It is part of the University Research Project entitled "A Study on Marketing of Organic Agricultural Products in Tamil Nadu", operated in the Department of Agricultural Economics, Tamil Nadu Agricultural University, Coimbatore- 641003.

\section{References}

Chandrasekaran, M., Anjugam, M., and Balasubramaniam, R. (2017). Strategies for Sustainable Organic Agriculture in Diversified Ecosystem. Innovative Research for Organic 3.0, 2, 9-11.

Dooren, I. (2005). Rice Value Chain Analysis: Each Life Start with a Little Seed.

Kaplinsky and, M. (2001). A Value Chain Analysis for the Srilankan Vegetables Subsector. The International Centre for Underutilized Crops

Meenaa, B., Anjugam, M., and Varadharaj, S. (2017). Consumer's Preference and Willingness to pay premium price for Organic Agricultural Products. International Conference on Organic Agriculture in the Tropics.

Nagarethinam, G. (2015). Value chain analysis of rice in Tamil Nadu. (Tamil Nadu Agricultural University, Coimbatore), India.

\section{How to cite this article:}

Anjugam M. and Alagumani T. 2019. Marketing Practices and Marketing Efficiency of Organic Minor Millets in Tamil Nadu, India. Int.J.Curr.Microbiol.App.Sci. 8(08): 2898-2905. doi: https://doi.org/10.20546/ijcmas.2019.808.334 